\title{
Coping with stress by Medical University students
}

\section{Zdzisława Szadowska-Szlachetka1 ${ }^{\oplus}$, Michał Drzewi² $^{2}$ Marta Łuczyk ${ }^{\circledR}$,

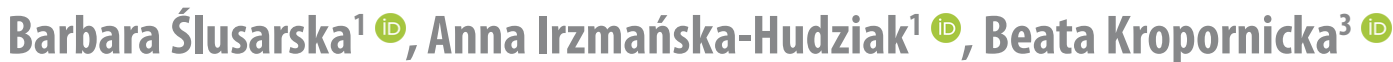

\author{
1Katedra Onkologii i Środowiskowej Opieki Zdrowotnej, Wydział Nauk o Zdrowiu, UM w Lublinie/ \\ Department of Oncology and Environmental Health, Faculty of Health Sciences, Medical University of Lublin \\ ${ }^{2}$ Absolwent Uniwersytetu Medycznego/Graduate of the Medical University \\ 3Katedra Interny z Zakładem Pielęgniarstwa Internistycznego, WNoZ UM w Lublinie/
} Chair of Internal Medicine and Department of Internal Medicine in Nursing, Faculty of Health Sciences, Medical University of Lublin

\section{CORRESPONDING AUTHOR/AUTOR DO KORESPONDENCJ: \\ Zdzisława Szadowska-Szlachetka \\ Katedra Onkologii i Środowiskowej Opieki Zdrowotnej \\ Wydział Nauk o Zdrowiu, UM w Lublinie \\ ul. Staszica 4/6, 20-081 Lublin \\ e-mail: zszadowska@wp.pl}

STRESZCZENIE

Słowa kluczowe:

ABSTRACT

Key words:

\section{RADZENIE SOBIE ZE STRESEM STUDENTÓW UNIWERSYTETU MEDYCZNEGO}

Wprowadzenie. Stres może być określany jako reakcja fizjologiczna i psychiczna na oddziałujące z zewnątrz bodźce (stresory) lub jako relacja między organizmem, a otoczeniem, która może oddziaływać nań w sposób negatywny, pozytywny lub neutralny.

Cel pracy. Niniejsza praca miała na celu zbadanie przyczyn występowania stresu wśród studentów, oraz określenie metod radzenia sobie z nim w odniesieniu do uwarunkowań socjodemograficznych.

Materiał i metody. Przebadano 117 studentów kierunku pielęgniarstwo za pomocą dwóch narzędzi standaryzowanych: Termometru Dystresu oraz Arkusza Mini Cope.

Wyniki. Nasilenie stresu wśród studentów kierunku pielęgniarstwo wynosiło średnio 6,3 - było wyższe od przeciętnej. Przyczyny stresu to: martwienie się, podenerwowanie, zmęczenie oraz praca i szkoła. Najczęściej wybierane strategie radzenia sobie ze stresem to aktywne radzenia sobie, poszukiwanie wsparcia emocjonalnego oraz poszukiwanie wsparcie instrumentalnego.

Wnioski. 1) Nasilenie stresu wśród studentów kierunku pielęgniarstwo było wyższe od wartości przeciętnej i wynosiło średnio 6,3. 2) Studenci wybierali konstruktywne metody radzenia sobie z nim to jest aktywne radzenie sobie, próba przezwyciężenia zaistniałej sytuacji, poszukiwanie wsparcia emocjonalnego i instrumentalnego. 3) Wiek badanych miał wpływ na wybór strategii „zaprzestanie działań" oraz na przyczynę stresu - „relacja z partnerem", a stan cywilny korelował z wystąpieniem objawu stresu „biegunka”.

przyczyny stresu, radzenie sobie ze stresem

\section{COPING WITH STRESS BY MEDICAL UNIVERSITY STUDENTS}

Introduction. Stress can be defined as a physiological and psychic response to external stimuli (stressors) or as a relationship between the body and the environment that can affect the body in a negative, positive or neutral way.

Aim. The aim of this paper was to investigate the causes of stress among students, and to identify methods of coping with it in relation to sociodemographic determinants.

Material and methods. The number of 117 nursing students were examined using two standardized tools: Distress Thermometer and Mini Cope Sheet.

Results. Intensity of stress among nursing students amounted to 6.3 , which was higher than the average. The causes of stress included: worrying, anxiety, fatigue, work, school. The most frequently chosen strategies for coping with stress are active coping, seeking emotional and instrumental support.

Conclusions. 1)Intensity of stress among nursing students was higher than the average and was equal to 6.3. 2) Students chose constructive methods of coping with it, i.e. active coping, trying to overcome the situation, searching for emotional and instrumental support. 3) The age of the respondents impacted the choice of the strategy of "cessation of activities" and the cause of stress „relationship with a partner" and marital status correlated with occurrence of symptom of stress - „diarrhea”. 


\section{INTRODUCTION}

Richard Lazarus observed in his research that stress and emotions, that accompany it, depend on the cognitive processes, namely the way an individual comprehends the situation and thus stress is one type of human-environment relation [1]. It can be positive-favourable, neutral or stressful [2]. Lazarus and Folkman distinguished the following ways of coping with stress:

- confrontation - defending one's position, dealing with difficulties in order to fulfil one's needs;

- planning a solution to a problem - coming up with the actions to resolve the stressful situation;

- distancing - undertaking actions aimed at moving away from the problem, avoiding thinking about it;

- avoidance - fantasizing, waiting, wishful thinking

- self-blame - self-criticism, self-aggression;

- self-control - refraining from negative emotions;

- seeking support - seeking help/assistance or sympathy from other people or institutions;

- positive reframing - seeking and emphasizing benefits of the stressful situation to reduce the feeling of loss and failure [1].

\section{AIM}

The aim of the study was the assessment of the causes and intensification of stress and the ways of coping in students of the Medical University of Lublin with regard to the sociodemographic factors.

\section{MATERIALS AND METHODS}

The study comprised 117 students of nursing at the Medical University of Lublin aged 19-31 years old. Females $88 \%(n=103)$ constituted a considerable majority of the students researched, compared to 14 males (12\%.) A total of $53 \%$ of the individuals researched lived in the rural areas $(n=62)$, while the remaining ones lived in the urban areas $47 \%(n=55)$. The majority of the students surveyed $(87.2 \%, n=102)$ declared being single and $12.8 \%$ of them $(n=15)$ were married.

Diagnostic survey was the research method utilised in the study, the technique involved in a survey and the research tools included the Distress Thermometer and Brief-COPE questionnaire. The Distress Thermometer is a two-part research tool: the first part is composed of a numerical scale used for determining the level of stress that ranges from zero to ten where zero means "no stress" and ten stands for "extreme stress". The values of one to five represent moderate but not health-threatening intensification of stress, whereas values exceeding five indicate significant intensification of stress and require psychological counselling. The second part of the Distress Thermometer comprises the list of thirty-five problems that might be the cause of stress. The problems are divided into several categories such as practical, family, emotional, spiritual (religious) and physical problems. A surveyed individual has two options to choose from i.e. "yes" or "no".
The Brief-COPE questionnaire is used to assess the ways of reacting to potentially stressful situations and to determine preferable coping strategies. The instrument includes twenty-eight statements that constitute fourteen coping strategies (scales). Individuals surveyed can obtain results from zero to three points, where zero represents "I haven't been doing this at all", one stands for "A little bit", two means "a medium amount" and three is "I've been doing this a lot".

The research was performed among the students of Medical University of Lublin from March to May 2019. Participation in the study was voluntary and the students gave an informed consent to take part. The results were presented by means of numerosity and percentage. The analysis was conducted with the non-parametric Chi-squared test and it was assumed that the values below 0.05 indicted statistical significance. The analysis was performed by means of the Start Soft Statistica 13.1 software.

\section{RESULTS}

According to the research performed, the mean level of stress measured with the Distress Thermometer was 6.3, which indicates that it is not extreme but higher than the average one, which requires psychological counselling in order to diagnose the causes of stress and determine typical coping strategies.

No statistically significant differences regarding the assumed sociodemographic variables were found. It is worth pointing out that the level of stress was the highest in students aged 27-30 years old since it reached 8.3.

The causes of stress included: worrying $-82.1 \%(n=96)$, work or studies $-79.5 \%(n=93)$, anxiety $-72.6 \%(n=85)$, tiredness - $63.2(n=74)$, being upset $-45.3 \%(n=53)$, relations with the partner $-31.6 \%(n=370)$, memory and concentration problems $-30.8 \%(n=36)$, diarrhoea $-9.4 \%$ $(n=11)$. In terms of the last cause of stress (diarrhoea), statistically significant differences regarding the age of the students researched were observed. The results were considerably higher in the research groups aged 27-30 years old and older than 30 years of age, which was $66.7 \%$ and $100 \%$ respectively ( $p=0.02542$ ). In the group of married students occurrence of diarrhoea was found in $26.7 \%$, which was statistically significant $(\mathrm{p}<0.014)$ - table 1 .

It was revealed that relationship with the partner was a stressful factor in $31.0 \%$ of students aged 19-22 years old and $22.2 \%$ of students $23-26$ years old. The results were considerably higher in students from 27 to 30 years of age and the ones older than 30 years old which amounted to $66.7 \%$ and $100 \%(\mathrm{p}<0.02)$ respectively - table 2 .

Out of the fourteen coping strategies presented in the Brief-COPE questionnaire, the most frequently chosen ones were active coping (mean 2.2) defined as undertaking activities aimed at improvement of the stressful situation, emotional and instrumental support (mean 2.1 for both), planning (mean 2.0) understood as attempting to plan what should be done to overcome the stressful situation, acceptance (mean 1.8) and positive reframing as well as self-distraction (mean 1.6 for both). Less frequently declared coping strategies included venting (mean 1.5), 
Zdzisława Szadowska-Szlachetka, Michał Drzewi, Marta Łuczyk, Barbara Ślusarska, Anna Irzmańska-Hudziak

Tab. 1. Diarrhoea as a cause of stress

\begin{tabular}{|c|c|c|c|c|c|c|c|c|c|c|c|c|}
\hline \multirow{2}{*}{\multicolumn{2}{|c|}{ Diarrhoea }} & \multirow{3}{*}{$\begin{array}{c}\text { Total } \\
11 \\
\end{array}$} & \multicolumn{2}{|c|}{ Sex } & \multicolumn{2}{|c|}{ Place of residence } & \multicolumn{4}{|c|}{ Age [years old] ${ }^{* *}$} & \multicolumn{2}{|c|}{ Marital status } \\
\hline & & & \multirow{2}{*}{$\begin{array}{c}\mathbf{F} \\
11\end{array}$} & \multirow{2}{*}{$\begin{array}{c}M \\
0\end{array}$} & \multirow{2}{*}{$\begin{array}{c}\mathbf{R} \\
7\end{array}$} & \multirow{2}{*}{$\begin{array}{l}\text { U } \\
4\end{array}$} & \multirow{2}{*}{$\begin{array}{c}19-22 \\
7\end{array}$} & \multirow{2}{*}{$\frac{23-26}{3}$} & \multirow{2}{*}{$\begin{array}{c}27-30 \\
0\end{array}$} & \multirow{2}{*}{$\begin{array}{c}>30 \\
1\end{array}$} & \multirow{2}{*}{$\frac{S}{7}$} & \multirow{2}{*}{$\begin{array}{c}\text { M } \\
4\end{array}$} \\
\hline & $\mathrm{n}$ & & & & & & & & & & & \\
\hline TLJ & $\%$ & $9.4 \%$ & $10.7 \%$ & $0.0 \%$ & $11.3 \%$ & $7.3 \%$ & $8.3 \%$ & $11.1 \%$ & $0.0 \%$ & $33.3 \%$ & $6.9 \%$ & $26.7 \%$ \\
\hline \multirow{2}{*}{ NO } & $n$ & 106 & 92 & 14 & 55 & 51 & 77 & 24 & 3 & 2 & 95 & 11 \\
\hline & $\%$ & $90.6 \%$ & $89.3 \%$ & $100 \%$ & $88.7 \%$ & $92.7 \%$ & $91.7 \%$ & $88.9 \%$ & $100 \%$ & $66.7 \%$ & $93.1 \%$ & $73.3 \%$ \\
\hline Total & $\mathrm{n}$ & 117 & 103 & 14 & 62 & 55 & 84 & 27 & 3 & 3 & 102 & 15 \\
\hline \multicolumn{2}{|c|}{ Stat: Chi^2.,p" } & - & \multicolumn{2}{|c|}{$\mathrm{p}=0.198$} & \multicolumn{2}{|c|}{$\mathrm{p}=0.457$} & \multicolumn{4}{|c|}{$\mathrm{p}=0.469$} & \multicolumn{2}{|c|}{$p=0.014$} \\
\hline
\end{tabular}

Tab. 2. Relationship with a partner as a cause of stress

\begin{tabular}{|c|c|c|c|c|c|c|c|c|c|c|}
\hline \multirow{2}{*}{\multicolumn{2}{|c|}{$\begin{array}{c}\text { Relationship } \\
\text { with } \\
\text { a partner }\end{array}$}} & \multirow{3}{*}{$\begin{array}{l}\text { 흉 } \\
\text { 으 } \\
37\end{array}$} & \multicolumn{2}{|c|}{ Sex } & \multicolumn{2}{|c|}{$\begin{array}{c}\text { Place of } \\
\text { residence }\end{array}$} & \multicolumn{4}{|c|}{ Age [years old] } \\
\hline & & & \multirow{2}{*}{\begin{tabular}{c|}
$\mathbf{K}$ \\
34 \\
\end{tabular}} & \multirow{2}{*}{\begin{tabular}{|c|}
$M$ \\
3 \\
\end{tabular}} & \multirow{2}{*}{$\begin{array}{l}\text { W } \\
17 \\
\end{array}$} & \multirow{2}{*}{$\begin{array}{l}\mathbf{M} \\
20 \\
\end{array}$} & \multirow{2}{*}{$\begin{array}{c}19-22 \\
26 \\
\end{array}$} & \multirow{2}{*}{$\begin{array}{c}23-26 \\
6 \\
\end{array}$} & \multirow{2}{*}{\begin{tabular}{|c|}
$27-30$ \\
2 \\
\end{tabular}} & \multirow{2}{*}{$\begin{array}{c}>30 \\
3\end{array}$} \\
\hline \multirow{2}{*}{ YES } & $n$ & & & & & & & & & \\
\hline & $\%$ & 31.6 & 33.0 & 21.4 & 27.4 & 36.4 & 31.0 & 22.2 & 66.7 & 100 \\
\hline \multirow{2}{*}{ NO } & $\mathrm{n}$ & 80 & 69 & 11 & 45 & 35 & 58 & 21 & 1 & 0 \\
\hline & $\%$ & 68.4 & 67.0 & 78.6 & 72.6 & 63.6 & 69.1 & 77.8 & 33.3 & 0.0 \\
\hline Total & $n$ & 117 & 103 & 14 & 62 & 55 & 84 & 27 & 3 & 3 \\
\hline \multicolumn{2}{|c|}{ Stat: Chi^ $2,{ }_{, \prime} \mathrm{p}^{\prime \prime}$} & - & \multicolumn{2}{|c|}{$p=0.38193$} & \multicolumn{2}{|c|}{$p=0.29908$} & \multicolumn{4}{|c|}{$p=0.02542$} \\
\hline
\end{tabular}

self-blame (mean 1.5), religion (mean 1.3) and humour (mean 1.0). The least frequently adopted coping strategies were co called non-adaptive coping strategies namely denial (mean 0.9), behavioural disengagement (mean 0.7) and substance use (mean 0.6) - table 3.

Having assessed coping strategies with regard to the age of the individuals researched, statistically significant differences were observed in "behavioural disengagement" for students aged 27 to 30 years old. The mean value was definitely higher compared to other age groups and equalled $1.2(\mathrm{p}=0.032)$. As for the professional status of the individuals surveyed, statistically significant differences were found in active coping. The mean value for the strategy was 2.1 in the students who were not professionally active and $2.49(\mathrm{p}=0.048)$ for those who studied and worked.

\section{DISCUSSION}

Chronic and excessive stress became an indispensable element of life in contemporary society. According to the authors' own research conducted with the Distress Thermometer, the level of stress in the students of Medical University of Lublin is higher than average - the mean value was 6.3 , whereas the safe value recommended by the authors of the instrument range from 0 to 5 . The value obtained suggests the need for psychological counselling. Similar results were presented in the research performed by Waghachavare, in which the level of stress declared by the students was also higher than the average [3]. In the research by Herberger conducted in a group of 120 students of University of Zielona Góra, stress level was average and did not diverge from the appropriate values [4]. In the authors' own research, variables such as place of residence, sex, professional status, age, marital status and education level did not have statistically significant relations with the level of stress. In the research conducted
Tab. 3. Coping strategies adopted by the students

\begin{tabular}{|l|c|c|c|c|c|c|}
\hline \multicolumn{2}{|c|}{ Total } & Mean & $\begin{array}{c}\text { Standard } \\
\text { deviation }\end{array}$ & Median & Minimum & Maximum \\
\hline 1. & Active Coping & 2.2 & 0.6 & 2.0 & 0.0 & 3.0 \\
\hline 2. & Planning & 2.0 & 0.7 & 2.0 & 0.0 & 3.0 \\
\hline 3. & $\begin{array}{c}\text { Positive } \\
\text { Reframing }\end{array}$ & 1.6 & 0.8 & 1.5 & 0.0 & 3.0 \\
\hline 4. & Acceptance & 1.8 & 0.6 & 2.0 & 0.0 & 3.0 \\
\hline 5. & Humour & 1.0 & 0.7 & 1.0 & 0.0 & 3.0 \\
\hline 6. & Religion & 1.3 & 1.0 & 1.5 & 0.0 & 3.0 \\
\hline 7. & $\begin{array}{c}\text { (Seeking) } \\
\text { Emotional } \\
\text { Support }\end{array}$ & 2.1 & 0.7 & 2.0 & 0.5 & 3.0 \\
\hline 8. & $\begin{array}{c}\text { (Seeking) } \\
\text { Instrumental } \\
\text { Support }\end{array}$ & 2.1 & 0.7 & 2.0 & 0.0 & 3.0 \\
\hline 9. & Self-distraction & 1.6 & 0.7 & 1.5 & 0.0 & 3.0 \\
\hline 10. & Denial & 0.9 & 0.7 & 0.0 & 0.0 & 3.0 \\
\hline 11. & Venting & 1.5 & 0.7 & 1.5 & 0.0 & 3.0 \\
\hline 12. & Substance Use & 0.6 & 0.7 & 0.0 & 0.0 & 2.5 \\
\hline 13. & $\begin{array}{c}\text { Behavioural } \\
\text { Disengagement }\end{array}$ & 0.7 & 0.6 & 0.5 & 0.0 & 2.5 \\
\hline 14. & Self-blame & 1.5 & 0.8 & 1.5 & 0.0 & 3.0 \\
\hline
\end{tabular}

in 457 students in Canada, Campbell proved that women were more susceptible to stress than men and students who came from the urban areas showed a less intensified level of stress compared to those living in the rural areas [5]. According to the authors' own research, the most common problems that contribute to stress intensification were: work/studies (79.5\%), anxiety (72.6\%) and tiredness (63.2\%). Essen and Owusu also indicated in their research work/studies (40\%) as the most frequently occurring causes of stress among students [6]. The following coping strategies were most often adopted by the students researched in the course of the study: "active coping", "seeking instrumental support", and "emotional support". It appears positive that the students very rarely turned to "substance use", "behavioural disengagement" or "denial". In the study by Szczyrba-Mardon performed in the students of nursing, the most frequently utilised coping strategies were "wishful thinking", "self-blame", whereas less common strategies included "active coping" and "seeking support". Similarly to the authors' own research, "substance use" was the least frequently adopted coping strategy [7].

The research by Dąbska and Wołoszynek also conducted among the students of Lublin universities indicated that they tend to use constructive ways of coping with stress, namely "active coping", "emotional support", 
"seeking instrumental support". Similarly to the authors' own research, it was confirmed that the students utilised "substance use" and "behavioural disengagement" the least frequently [8].

However, the research by Piątkowski and Skrzypek revealed that men chose strategies focused on solving the problem and seeking the causes of the stressful situation definitely more frequently. Women considerably more often applied coping strategies that involved providing emotional support, compensating and being passive towards the situation [9].

The age of the individuals researched affected the choice of only one coping strategy namely "behavioural disengagement". The students aged from 27 to 30 years old tended to adopt this strategy more often, compared to the remaining age groups. In the research by Skrzypek and Piątkowski, along with an increase in the students' age, more participants used the strategies concerned with solving the problem and active coping with the stress evoking situation. Moreover, few individuals applied strategies focused on emotional and instrumental support [9].

In our study marital status did not affect the choice of a coping strategy. Both single and married individuals adopted "active coping" most often. Another commonly used coping strategy was "seeking emotional and instrumental support" and "planning". In the research by Ruchi and Ravindra, married participants chose effective coping strategies more often than the single ones [10]. In the authors' own research no statistical significance was found with regard to the effect of level of education (Bachelor's degree and Master's degree) on the preferred coping strategies - students of both academic courses most frequently utilised "active coping" and "planning" - however, the strategies were more common in Master's degree students.

Piątkowski and Skrzypek observed that students from Master's degree studies chose constructive coping strategies more often [9]. Having analysed the relationship between the professional status of the students surveyed with their choice of coping strategies in the authors' research, statistically significant differences were revealed with regard to "active coping" - individuals who studied and worked chose this strategy more frequently (mean 2.4) compared to those who only studied (mean 2.1 ). On the basis of the results obtained it can be assumed that individuals who study and work, despite having less free time, can cope with stress in a more constructive way.

\section{CONCLUSIONS}

1. Students, despite a high intensity of stress, adopted constructive coping methods: active coping, attempting to overcome the situation, as well as seeking emotional and instrumental support.

2. The least frequently chosen coping strategies included substance use and denial.

3. The age of the individuals researched affected their choice of the coping strategy, namely behavioural disengagement and the cause of stress - relationship with the partner. Marital status correlated with the occurrence of a stress symptom such as diarrhoea.

\section{Radzenie sobie ze stresem studentów Uniwersytetu Medycznego}

\section{WPROWADZENIE}

Richard Lazarus w swoich badaniach stwierdził, że stres i towarzyszące mu emocje zależą od przebiegu procesów poznawczych, czyli sposobu pojmowania danej sytuacji przez człowieka, a stres jest jednym z typów relacji człowiek-otoczenie [1.]

Relacja ta może być: pozytywno- sprzyjająca, neutralna i stresująca [2].

Lazarus i Folkman wyróżnili następujące sposoby radzenia sobie ze stresem:

- konfrontacja - obrona własnego stanowiska, walka z trudnościami, by zaspokoić swoje potrzeby;

- planowanie rozwiązania problemu - zaplanowane działanie wobec sytuacji stresowej;

- dystansowanie się - podejmowanie wysiłków mających na celu odsunięcie od siebie problemu, unikanie myślenia o nim;

- unikanie/ucieczka - fantazjowanie, przeczekiwanie, myślenie życzeniowe;

- samoobwinianie się - samokrytyka, autoagresja;
- samokontrola - powstrzymywanie negatywnych emocji;

- poszukiwanie wsparcia - szukanie pomocy lub współczucia ze strony innych ludzi lub instytucji;

- pozytywne przewartościowanie - szukanie i podkreślanie dobrych stron sytuacji stresowej, aby zmniejszyć poczucie straty lub porażki [1].

\section{CEL PRACY}

Celem pracy była ocena przyczyn i nasilenia stresu oraz sposobów radzenia sobie $z$ nim przez studentów Uniwersytetu Medycznego w zależności od czynników socjodemograficznych.

\section{MATERIAŁ I METODY}

Badaniem zostało objętych 117 studentów Uniwersytetu Medycznego, w wieku 19-31 lat kierunku pielęgniarstwo w Lublinie. Zdecydowaną większość badanych stanowiły kobiety- 88\% ( $\mathrm{n}=103)$, mężczyzn było 14 (12\%.) Mieszkańcy wsi to $53 \%$ ogółu badanych $(n=62)$, pozostali 
zamieszkiwali w mieście 47\% $(n=55)$.Większość $(87,2 \%$, $\mathrm{n}=102$ ) zadeklarowała stan cywilny wolny, a $12,8 \%$ badanych $(n=15)$ było w związku małżeńskim.

Metodą badawczą zastosowaną w pracy był sondaż diagnostyczny, techniką wywiad, zaś narzędzia badawcze to Termometr Dystres oraz Arkusz Mini Cope. Termometr Dystresu jest dwuczęściowym narzędziem badawczym: pierwszą część stanowi numeryczna skala służąca do określenia poziomu stresu badanego w zakresie od zera do dziesięciu gdzie zero oznacza „brak stresu”, natomiast dziesięć „stres ekstremalny”; wartości od jednego do pięciu oznaczają średnie ale nie zagrażające zdrowiu nasilenie stresu, zaś i powyżej pięciu wskazują na znaczne nasilenie stresu i konieczność konsultacji psychologicznej. Drugą część Termometru Dystresu stanowi lista trzydziestu pięciu problemów mogących stanowić przyczynę stresu. Problemy te podzielone są na kilka kategorii: problemy praktyczne, rodzinne, emocjonalne, duchowe (religijne) oraz fizyczne.

Ankietowany ma dwie możliwości wyboru: „tak” lub „nie. Kwestionariusz Mini Cope służy do oceny sposobu reagowania na sytuację potencjalnie stresującą oraz określenie wyboru strategii radzenia sobie ze stresem. Składa się z dwudziestu ośmiu twierdzeń tworzących czternaście strategii radzenia sobie ze stresem (subskal), gdzie można uzyskać wyniki od zera do trzech punktów. gdzie zero oznacza „prawie nigdy tak nie postępuję”, jeden „rzadko tak postępuję”, dwa "często tak postępuję” oraz trzy „prawie zawsze tak postępuję”. Badania przeprowadzono w miesiącach marzec - maj 2019 roku wśród studentów Uniwersytetu Medycznego w Lublinie. Udział w ankiecie był dobrowolny, studenci wyrazili nań zgodę.

Wyniki badań przedstawiono za pomocą liczebności i odsetka, w celu sprawdzenia istotnych statystycznie zależności przeprowadzono analizę za pomocą nieparametrycznego testu Chi Kwadrat Pearsona-przyjęto, iż uzyskanie wartości poniżej 0,05 wskazuje na występowanie istotności statystycznej. Analizę wykonano za pomocą pakietu statystycznego Start Soft Statistica 13.1.

\section{WYNIKI BADAŃ}

Z przeprowadzonych badań wynika, że wśród ogółu ankietowanych średni poziom stresu obliczony za pomocą Termometru Dystresu wyniósł 6,3. Wynik taki oznacza, że poziom stresu wśród badanej grupy nie jest co prawda ekstremalny, ale jest wyższy od przeciętnej i oznacza konieczność konsultacji z psychologiem w celu zdiagnozowania przyczyn stresu i ustalenia strategii radzenia sobie $\mathrm{z}$ nim.
Nie znaleziono istotnych statystycznych różnic ze względu na przyjęte w pracy zmienne socjodemograficzne. Na uwagę zasługuje jednak fakt, że poziom stresu był zdecydowanie najwyższy w grupie wiekowej 27-30 lat i wynosił 8,3 .

Jeżeli chodzi najczęstsze powody stresu badanych to było to : martwienie się $-82,1 \%(n=96)$, praca oraz szkoła - 79,5\% badanych $(n=93)$, podenerwowanie $-72,6 \%$ $(\mathrm{n}=85)$, zmęczenie $63,2 \%(\mathrm{n}=74)$,występowanie uczucia smutku $(45,3 \%, n=53)$, relacje $\mathrm{z}$ partnerem $31,6 \%$ badanych $(n=37)$, problemy z pamięcią i koncentracją $-30,8 \%$ badanych $(n=36)$, występowanie biegunki - 9,4\% badanych $(n=11)$. W odniesieniu do ostatniego powodu stresu wykazano istotne statystycznie różnice ze względu na stan cywilny. Wśród osób żyjących w sformalizowanym związku występowanie biegunki zanotowano u 26,7\% badanych, co było istotne statystycznie $(\mathrm{p}<0,05)$ - tabela 1 .

W grupach wiekowych 19-22 lat oraz 23-26 lat relacje z partnerem jako czynnik stresujący uznało odpowiednio $31,0 \%$ oraz $22,2 \%$, w dwu pozostałych grupach wiekowych tj. 27-30 lat oraz powyżej 30 lat wskaźnik ten był zdecydowanie wyższy i wynosił odpowiednio $66,7 \%$ oraz $100 \%(\mathrm{p}<0,02)$ - tabela 2 .

Spośród czternastu strategii radzenia sobie ze stresem zawartych w arkuszu Mini Cope najczęściej wybierane było aktywne radzenia sobie (średnia 2,2) definiowanie jako „podejmowanie działań mających na celu poprawę sytuacji”, poszukiwanie wsparcia emocjonalnego oraz poszukiwanie wsparcie instrumentalnego (w obu przypadkach średnia 2,1), „planowanie” (średnia 2,0) czyli „próba zaplanowania co należy zrobić, aby przezwyciężyć zaistniałą sytuację), „akceptacja zaistniałej sytuacji” (średnia 1,8 ) oraz „pozytywne przewartościowanie” i „zajmowanie się czymś innym” (w obu przypadkach średnia 1,6). Do rzadziej wybieranych metod radzenia sobie ze stresem wskazanych przez badaną grupę można zaliczyć : „wyładowanie” (średnia 1,5), „obwinianie siebie”(średnia 1,5), "Zwrot ku religii” (średnia 1,3) oraz „poczucie humoru” (średnia 1,0). Najrzadziej wybierane były tzw. „negatywne sposoby radzenia sobie ze stresem” tzn. „zaprzeczanie” (średnia 0,9) ," zaprzestanie działań” (średnia 0,7) oraz "zażywanie substancji psychoaktywnych" (średnia 0,6)tabela 3.

W ocenie sposobów radzenia sobie ze stresem ze względu na wiek badanych osób istotne statystycznie różnice zauważono w strategii radzenia sobie ze stresem „zaprzestanie działań": w przedziale wiekowym 27-30 lat, średnia ta była zdecydowanie wyższa niż w innych grupach i wyniosła $1,2(\mathrm{p}=0.032)$. Ze względu na status zawodowy

Tab. 1. Biegunka jako problem powodujący występowanie stresu

\begin{tabular}{|c|c|c|c|c|c|c|c|c|c|c|c|c|}
\hline \multirow{2}{*}{\multicolumn{2}{|c|}{ Biegunka }} & \multirow{3}{*}{$\begin{array}{c}\text { Razem } \\
11\end{array}$} & \multicolumn{2}{|c|}{ Płeć } & \multicolumn{2}{|c|}{ Miejsce zamieszkania } & \multicolumn{4}{|c|}{ Wiek [lat] ${ }^{* *}$} & \multicolumn{2}{|c|}{ Stan cywilny } \\
\hline & & & \multirow{2}{*}{$\begin{array}{c}\mathbf{K} \\
11\end{array}$} & \multirow{2}{*}{$\begin{array}{c}\text { M } \\
0\end{array}$} & \multirow{2}{*}{$\frac{W}{7}$} & \multirow{2}{*}{$\frac{\text { M }}{4}$} & \multirow{2}{*}{$\begin{array}{c}19-22 \\
7\end{array}$} & \multirow{2}{*}{$\frac{23-26}{3}$} & \multirow{2}{*}{$\frac{27-30}{0}$} & \multirow{2}{*}{$\frac{>30}{1}$} & \multirow{2}{*}{$\begin{array}{c}\mathrm{P} / \mathbf{K} \\
7\end{array}$} & \multirow{2}{*}{$\frac{\mathbf{Z} / \mathbf{Z}}{4}$} \\
\hline T & $\mathrm{n}$ & & & & & & & & & & & \\
\hline тил & $\%$ & $9,4 \%$ & $10,7 \%$ & $0,0 \%$ & $11,3 \%$ & $7,3 \%$ & $8,3 \%$ & $11,1 \%$ & $0,0 \%$ & $33,3 \%$ & $6,9 \%$ & $26,7 \%$ \\
\hline \multirow{2}{*}{ NIE } & $\mathrm{n}$ & 106 & 92 & 14 & 55 & 51 & 77 & 24 & 3 & 2 & 95 & 11 \\
\hline & $\%$ & $90,6 \%$ & $89,3 \%$ & $100 \%$ & $88,7 \%$ & $92,7 \%$ & $91,7 \%$ & $88,9 \%$ & $100 \%$ & $66,7 \%$ & $93,1 \%$ & $73,3 \%$ \\
\hline Ogółem & $\mathrm{n}$ & 117 & 103 & 14 & 62 & 55 & 84 & 27 & 3 & 3 & 102 & 15 \\
\hline \multicolumn{2}{|c|}{ Stat: Chi $^{\wedge} 2,{ }_{, \prime}{ }^{\prime \prime}$} & - & \multicolumn{2}{|c|}{$p=0,198$} & \multicolumn{2}{|c|}{$p=0,457$} & \multicolumn{4}{|c|}{$p=0,469$} & \multicolumn{2}{|c|}{$p=0,014$} \\
\hline
\end{tabular}


- Tab. 2. Relacje z partnerem jako problem przyczyniający się do powstania stresu

\begin{tabular}{|c|c|c|c|c|c|c|c|c|c|c|}
\hline \multirow{2}{*}{\multicolumn{2}{|c|}{$\begin{array}{c}\text { Relacje } \\
\text { z partnerem }\end{array}$}} & \multirow{3}{*}{ 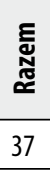 } & \multicolumn{2}{|c|}{ Płeć } & \multicolumn{2}{|c|}{$\begin{array}{c}\text { Miejsce } \\
\text { zamieszkania }\end{array}$} & \multicolumn{4}{|c|}{ Wiek [lat] } \\
\hline & & & \multirow{2}{*}{$\frac{K}{34}$} & \multirow{2}{*}{$\frac{M}{3}$} & \multirow{2}{*}{$\begin{array}{l}\text { W } \\
17\end{array}$} & \multirow{2}{*}{$\begin{array}{l}M \\
20\end{array}$} & \multirow{2}{*}{$\frac{19-22}{26}$} & \multirow{2}{*}{\begin{tabular}{|c|}
$23-26$ \\
6 \\
\end{tabular}} & \multirow{2}{*}{$\begin{array}{c}27-30 \\
2 \\
\end{array}$} & \multirow{2}{*}{$\frac{>30}{3}$} \\
\hline \multirow{2}{*}{ TAK } & $\mathrm{n}$ & & & & & & & & & \\
\hline & $\%$ & 31,6 & 33,0 & 21,4 & 27,4 & 36,4 & 31,0 & 22,2 & 66,7 & 100 \\
\hline \multirow{2}{*}{ NIE } & $\mathrm{n}$ & 80 & 69 & 11 & 45 & 35 & 58 & 21 & 1 & 0 \\
\hline & $\%$ & 68,4 & 67,0 & 78,6 & 72,6 & 63,6 & 69,1 & 77,8 & 33,3 & 0,0 \\
\hline Ogółem & $\mathrm{n}$ & 117 & 103 & 14 & 62 & 55 & 84 & 27 & 3 & 3 \\
\hline \multicolumn{2}{|c|}{ Stat: Chi^2, „1" } & - & \multicolumn{2}{|c|}{$\mathrm{p}=0,38193$} & \multicolumn{2}{|c|}{$p=0,29908$} & \multicolumn{4}{|c|}{$p=0,02542$} \\
\hline
\end{tabular}

badanej grupy, dostrzeżono istotne statystycznie różnice w strategii aktywne radzenie sobie. Wśród osób studiujących średnia dla tej strategii wyniosła 2,1 , a wśród osób studiujących i pracujących średnia była wyższa i wynosiła 2,49 ( $p=0,048)$.

\section{DYSKUSJA}

Chroniczny nadmierny stres stał się nieodłączną częścią funkcjonowania współczesnych społeczeństw. $Z$ badań własnych dokonanych za pomocą Termometru Dystresu wynika, iż poziom stresu studentów Uniwerystetu Medycznego jest ponadprzeciętny- średni wynik wśród badanych wynosił 6,3 podczas, gdy bezpieczna wartość deklarowana przez autorów tego narzędzia badawczego, waha się od 0 do 5 . Uzyskany wynik powinien być podstawą do przeprowadzenia konsultacji psychologicznej. Podobnie kształtowały się wyniki badań przeprowadzone przez Waghachavare- w badaniach tych również stwierdzono, iż poziom stresu wśród studentów jest ponadprzeciętny [3]. W badaniach Herbergera przeprowadzonych wśród 120 studentów Uniwersytetu Zielonogórskiego poziom stresu badanej grupy był przeciętny i nie odbiegający od prawidłowych wartości [4].W badaniach własnych zmienne takie jak miejsce zamieszkania, płeć, status zawodowy, wiek, stan cywilny oraz poziom kształcenia nie miały związku istotnego statystycznie z poziomem stresu. W badaniach przeprowadzonych wśród 457 studentów w Kanadzie, Campbell wykazał, że kobiety są grupą dużo bardziej narażoną na występowanie stresu niż mężczyźni, a studenci pochodzący z miasta wykazywali mniejsze nasilenie stresu od zamieszkałych na wsi [5]. Z badań własnych wynikało, iż najczęściej występującymi problemami przyczyniającymi się do powstawania stresu wśród badanych była praca/szkoła (79,5\%), podenerwowanie $(72,6 \%)$, oraz zmęczenie $(63,2 \%)$. Essen oraz Owusu w swoich badaniach za najczęstsze problemy przyczyniające się do powstawania stresu wśród studentów również wskazali pracę/szkołę (40\%)[6]. W badaniach własnych studenci wybierali najczęściej następujące strategie radzenia sobie ze stresem: „aktywne radzenie sobie”, „poszukiwanie wsparcia instrumentalnego” oraz „poszukiwania wsparcia emocjonalnego". Bardzo pozytywne jest to, że „zażywanie substancji psychoaktywnych i leków” również „zaprzestanie działań” i „zaprzeczanie” były bardzo rzadko wybierane przez studentów. W badaniach Szczyrba-Maroń przeprowadzonych wśród studentów pielęgniarstwa najczęściej wybieraną strategią radzenia sobie
- Tab. 3. Strategie radzenia sobie ze stresem wybierane przez studentów

\begin{tabular}{|c|c|c|c|c|c|c|}
\hline \multicolumn{2}{|r|}{$\begin{array}{l}\text { Wszyscy badani } \\
\text { razem }\end{array}$} & \multirow{2}{*}{\begin{tabular}{|c|} 
Średnia \\
2,2 \\
\end{tabular}} & \multirow{2}{*}{\begin{tabular}{|c|}
$\begin{array}{c}\text { Odch. } \\
\text { std }\end{array}$ \\
0,6
\end{tabular}} & \multirow{2}{*}{$\begin{array}{c}\text { Mediana } \\
2,0\end{array}$} & \multirow{2}{*}{$\begin{array}{c}\text { Minimum } \\
0,0\end{array}$} & \multirow{2}{*}{$\begin{array}{c}\text { Maksimum } \\
3,0\end{array}$} \\
\hline 1. & $\begin{array}{c}\text { Aktywne Radzenie } \\
\text { Sobie }\end{array}$ & & & & & \\
\hline 2. & Planowanie & 2,0 & 0,7 & 2,0 & 0,0 & 3,0 \\
\hline 3. & $\begin{array}{c}\text { Pozytywne } \\
\text { przewartościowanie }\end{array}$ & 1,6 & 0,8 & 1,5 & 0,0 & 3,0 \\
\hline 4. & Akceptacja & 1,8 & 0,6 & 2,0 & 0,0 & 3,0 \\
\hline 5. & Poczucie humoru & 1,0 & 0,7 & 1,0 & 0,0 & 3,0 \\
\hline 6. & Zwrot ku religii & 1,3 & 1,0 & 1,5 & 0,0 & 3,0 \\
\hline 7. & $\begin{array}{l}\text { Poszukiwanie } \\
\text { wsparcia } \\
\text { emocjonalnego } \\
\end{array}$ & 2,1 & 0,7 & 2,0 & 0,5 & 3,0 \\
\hline 8. & $\begin{array}{c}\text { Poszukiwanie } \\
\text { wsparcia } \\
\text { instrumentalnego }\end{array}$ & 2,1 & 0,7 & 2,0 & 0,0 & 3,0 \\
\hline 9. & $\begin{array}{c}\text { Zajmowanie się } \\
\text { czymś innym }\end{array}$ & 1,6 & 0,7 & 1,5 & 0,0 & 3,0 \\
\hline 10. & Zaprzeczanie & 0,9 & 0,7 & 0,0 & 0,0 & 3,0 \\
\hline 11. & Wyładowanie & 1,5 & 0,7 & 1,5 & 0,0 & 3,0 \\
\hline 12. & $\begin{array}{c}\text { Zażywanie } \\
\text { substancji } \\
\text { psychoaktywnych }\end{array}$ & 0,6 & 0,7 & 0,0 & 0,0 & 2,5 \\
\hline 13. & $\begin{array}{c}\text { Zaprzestanie } \\
\text { działań }\end{array}$ & 0,7 & 0,6 & 0,5 & 0,0 & 2,5 \\
\hline 14. & Obwinainie siebie & 1,5 & 0,8 & 1,5 & 0,0 & 3,0 \\
\hline
\end{tabular}

ze stresem wśród badanych było „myślenie życzeniowe”, „obwinianie się”, a rzadziej wybierano „aktywne radzenie sobie” i „poszukiwanie wsparcia” oraz podobnie jak w przeprowadzonych przeze mnie badaniach „zażywanie substancji psychoaktywnych i leków ”, które było najrzadziej wybieraną strategia radzenia sobie ze stresem [7].

Badania Dąbskiej i Wołoszynek dotyczące również studentów lubelskich uczelni także wskazały na wybieranie przez nich konstruktywnych sposobów radzenia sobie ze stresem t.j „aktywnego radzenie sobie”, „poszukiwania wsparcia emocjonalnego", „poszukiwania wsparcia instrumentalnego" i najrzadziej podobnie jak w przeprowadzonych przeze mnie badaniach: „zażywanie substancji psychoaktywnych” oraz „zaprzestania działań” [8].

Natomiast badania Piątkowskiego i Skrzypka ukazały, że mężczyźni zdecydowanie częściej wybierali strategie zorientowane na rozwiązanie problemu oraz poszukiwanie przyczyny zaistniałej sytuacji zaś kobiety zdecydowanie częściej wybierały strategie zorientowane na udzielanie wsparcia emocjonalnego, a także metody kompensacji i bierności wobec zaistniałej sytuacji [9].

Wiek badanych miał wpływ na wybór tylko jednej z czternastu strategii (zaprzestanie działań)- strategia ta była częściej wybierana przez osoby w przedziale wiekowym 27-30 lat niż w pozostałych grupach wiekowych. W badaniach Skrzypka i Piątkowskiego wraz ze wzrostem wieku badanych więcej osób wybierało style radzenia sobie ze stresem zorientowane na rozwiązywanie problemu oraz aktywne radzenie sobie $\mathrm{z}$ zaistniałą sytuacją stresową a malała liczba osób wybierających strategie zorientowane na wsparcie zarówno emocjonalne jak i instrumentalne [9].

W badaniach własnych stan cywilny nie miał wpływu na wybór strategii radzenia sobie ze stresem. Zarówno osoby w stanie wolnym jak i żyjące w związku najczęściej 
wybierały „aktywne radzenie sobie”. Częstym wyborem spośród strategii radzenia sobie ze stresem było także ”, poszukiwanie wsparcia zarówno instrumentalnego jak i emocjonalnego” oraz „planowanie”. W badaniach Ruchi oraz Ravindra osoby pozostające w związku wybierały częściej konstruktywne sposoby radzenia sobie ze stresem niż osoby stanu wolnego [10]. W badaniach własnych nie wykazano istotności statystycznej dotyczącej wpływu poziomu kształcenia(studia pierwszego i drugiego stopnia) na przyjęte strategie radzenia sobie ze stresem zarówno studenci studiów licencjackich jak i magisterskich najczęściej wybierali „aktywne radzenie sobie” oraz „planowanie” - metody te były jednak częstsze w przypadku studentów studiów magisterskich.

Piątkowski i Skrzypek zbadali, że osoby będące na wyższym poziomie kształcenia(studia magisterskie) częściej wybierały konstruktywne metody radzenia sobie ze stresem [9].

Analizując związek statusu zawodowego badanych $\mathrm{z}$ wyborem strategii radzenia sobie ze stresem, zauważono w badaniach własnych istotne statystycznie różnice w strategii „aktywne radzenie sobie”- osoby studiujące i pracujące częściej wybierały tę strategię (średnia 2,4) w porównaniu do osób tylko studiujących (średnia 2,1), na podstawie tych wyników można domniemać, iż osoby studiujące i pracujące pomimo, iż posiadają mniej wolnego czasu potrafią w sposób bardziej konstruktywny radzić sobie ze stresem.

\section{WNIOSKI}

1. Studenci pomimo dużego nasilenia stresu wybierali konstruktywne metody radzenia sobie z nim: aktywne radzenie sobie, próba przezwyciężenia zaistniałej sytuacji, poszukiwanie wsparcia emocjonalnego i instrumentalnego.

2. Najrzadziej wybieranymi metodami radzenia sobie ze stresem było zażywanie substancji psychoaktywnych oraz zaprzeczenie zaistniałej sytuacji.

3. Wiek badanych miał związek z wyborem strategii „zaprzestanie działań” oraz z przyczyną stresu - „relacja z partnerem”, a stan cywilny korelował z wystąpieniem objawu stresu „biegunka”.

\section{ORCID}

ZdzisławaSzadowska-Szlachetka (iD https://orcid.org/0000-0001-9325-842X Barbara Ślusarska (D) https://orcid.org/0000-0003-0101-9216 Marta Łuczyk (iD https://orcid.org/0000-0002-4578-8722

Anna Irzmańska-Hudziak (iD https://orcid.org/0000-0003-4446-2592

Beata Kropornicka (iD) https://orcid.org/0000-0002-7634-1579

\section{REFERENCES/PIŚMIENNICTWO}

1. Lazarus R. Paradygmat stresu i radzenia sobie. Nowiny Psychologiczne. 1986;3: 4041.

2. Ogińska-Bulik N. Stres zawodowy i jego konsekwencje w grupie pracowników sektora usług społecznych - rola inteligencji emocjonalnej. Przegląd Psychologiczny. 2006;1:69-85.

3. Waghachavare V. A Study of Stress among Students of Professional Colleges from an Urban area in India. Sultan Qaboos Univ Med Journal. 2013;13: 429-436.

4. Herberger J. Poziom stresu związanego ze studiami i jego wybrane uwarunkowania. Psychologiczne zeszyty naukowe. 2016; 1: 61-74.

5. Campbell R. Perceived Level of Stress among University Undergraduate Students in Edmonton, Canada. Sage Journals. 1992;75: 552-554.

6. Owusu P, Essel G. Causes of students' stress, its effects on their academic success, and stress management by students, Case study at Seinäjoki University of Applied Sciences, Finland. Seinaioki University of Apllied Sciences. 2017; 30-61.

7. Szczyrba M. Strategie radzenia sobie ze stresem w grupie studentów pielęgniarstwa z uwzględnieniem korzystania ze środków psychoaktywnych. Problemy Pielęgniarstwa. 2010;4:455-460.

8. Dąbska 0, Wołoszynek E, Kowalczyk A, et al. Sposoby radzenia sobie ze stresem badanie ankietowe studentów wybranych szkół wyższych z Lublina. Pielęgniarstwo iZdrowie Publiczne. 2017; 7: 27-34

9. Piątkowski W, Skrzypek M. Analiza jakości życia studentów w kontekście stylu radzenia sobie ze stresem. Raport z Badań Annales Universitatis Mariae CuriaeSkłodowska. Sectio I, Philosophia-Sociologia. 2001; 26: 261-275.

10. Ruchi S, Ravindra K. Depression and Life Satisfaction among Married \& Unmarried Women. IOSR Journal Of Humanities And Social Science (IOSR-JHSS). 2013; 16: 33-36.

Manuscript received/Praca zgłoszona do czasopisma: 21.10.2019

Manuscript accepted/Praca zaakceptowana do druku: 13.02.2020

Translation/Tłumaczenie: Anna Goś 